\title{
PENGARUH VARIASI CAMPURAN TEPUNG DAUN KELOR (Moringaoleifera L) DAN BEKATUL TERHADAP PERTUMBUHAN AYAM KAMPUNG (Gallus-gallus domesticus. Var. Ayam Joper) SEBAGAI SUMBER BELAJAR BIOLOGI
}

\author{
Wisca Febriana ${ }^{1}$ \\ Agus Sutanto ${ }^{2}$ \\ Suharno Zen ${ }^{3}$ \\ 1, 2, 3, Pendidikan Biologi Universitas Muhammadiyah Metro \\ E-mail: ${ }^{1}$ wiscafebriana10@gmail.com, ${ }^{2}$ sutanto11@gmail.com, ${ }^{3}$ suharnozein@gmail.com
}

\begin{abstract}
The research about the mixture of moringa leaf flour and rice bran on the growth of orgainic chicken on Joper chicken. var as a source of learning biology aims to determine the effect of feed from the mixture of moring a leafflour (Moringa oleifera $L$ ) and rice bran on the growth of organic chickens (Gallus-gallus domesticus L. Joper chicken. var), then to find out certain variations of the mixture of moringa leaf flour (Moringa oleifera $L$ ) and rice bran which gives the best influence and to make posters that are used as a source of high school biology learning. The method used is a completely randomized design (CRD), experiments conducted with 3 treatments and 1 control. Control (0\% moringa leaf flour), P1 (2.5\% moringa leaf flour), P2 (5\% moring a leaf flour) and P3 (7.5\% moringa leaf flour). The parameters observed were weight, length, and diameter of the joper body.The results of the study were tested using a non-parametric statistical test or commonly called the kruskal wallis test. Kruskal wallis test results on chicken weight obtained X2value $4.09<X 2$ table 14.07 at $\alpha 0.05$ means Ho is accepted, length measurements obtained results X2value $=3.61<X 2$ table $=14.07$ at $\alpha 0.05$ means Ho is accepted, diameter measurements obtained results X2 value $=4.2<X 2$ table $=14.07$ at $\alpha 0.05$ means $H o$ is accepted.The conclusion from this study was the feed from the mixture of moringa leaf flour and rice bran did not have a significant effect on the growth of joper. The results of the used ranking from $5 \%$ Moring leafflour gave the best effect for weight gain of joper. Based on the results of the validation of learning resources shows that learning resources in the form of posters that are made were feasible to be used as a source of learning biology for high school students.
\end{abstract}

Kata kunci: super java chicken, Indigofera, alternative feed, poster learning resources

\section{PENDAHULUAN}

Kebutuhan akan protein menjadi kebutuhan primer yang harus dipenuhi oleh masyarakat. Kebutuhan protein hewani selalu meningkat setiap tahunnya seiring dengan bertambahnya jumlah penduduk dan kesadaran masyarakat akan pentingnya protein terutama protein hewani dalam memenuhi kebutuhan gizinya. Protein hewani dapat berupa telur, susu, ikan dan daging. Semua daging mempunyai nilai protein yang tinggi termasuk daging ayam. Ayam mempunyai banyak jenisnya, salah satunya adalah ayam joper. Ayam joper merupakan ayam persilangan antara ayam kampung dan ayam bangkok atau bisa dengan ayam broiler.

Keberadaan peternak ayam merupakan solusi yang tepat dalam memenuhi kebutuhan nutrisi bagi masyarakat, karena dengan masa panen ayam yang relatif cepat akan membuat masyarakat lebih mudah untuk mendapatkan daging ayam sebagai sumber protein hewaninya. Namun masih sedikit masyarakat yang kurang berminat beternak ayam, salah satu alasannya 
adalah faktor biaya pemeliharaan ayam cukup tinggi.

Pakan merupakan salah satu komponen yang terpenting dalam suatu peternakan. Pakan merupakan sumber energi untuk kelangsungan hidup ayam, dan disisi lain pakan merupakan biaya produksi terbesar dalam peternakan. Pakan alami yang memanfaatkan tanaman dan bahan-bahan disekitar menjadi alternatif untuk mengurangi biaya produksi pakan.Pakan alami dapat dibuat dengan memanfaatkan tanaman kelor dan bekatul.

Daun kelor (Moringa oleifera L.) merupakan tanaman yang dapat tumbuh dimana saja bahkan dapat dijadikan sebagai tanaman hias. Tanaman Kelorini tumbuh dalam bentuk pohon, berumur panjang, ketinggian dapat mencapai 12 $\mathrm{m}$, batang berkayu, tegak, berwarna kotor, berkulit tipis dan permukaan kasar (Krisnadi, 2015). Tanaman kelor mengandung nutrisi yang cukup banyak, mempunyai vitamin paling lengkap dibandingkan tanaman lainnya, dan mengandung semua asam amino (Tilong, 2012).

Bekatul dinilai sebagai bahan kurang bermanfaat karena bekatul merupakan limbah dalam proses pengolahan gabah menjadi beras. Sejak dulu bekatul hanya dikenal masyarakat sebagai bahan pakan ternak dengan mutu yang rendah (Wulandari, 2010). Bekatul mempunyai nilai gizi yang cukup tinggi, yaitu asam amino seperti: triptofan, histidin, sistein, dan arginin. Jenis serat pangan terdiri atas selulosa, hemiselulosa, pectin, arabinosilan, lignin, dan $\beta$-glukan. Selain itu bekatul juga mengandung beberapa komponen bioaktif, seperti $\gamma$-oryzanol, asam ferulat, asam kafeat, tricine, asam kumarat, asam fitat, isoform vitamin $\mathrm{E}$ ( $\alpha$-tokoferol, $\gamma$ tokoferol, tokotrienol) fitosterol $(\beta$ sitosterol, stigmasterol, kampesterol), dan karotenoid (Tuarita dkk, 2017)

Asrul (2016) melaporkan bahwa pertambahan bobot ayam cenderung meningkat dengan ditambahkannya daun kelor sebanyak 6\% jika dibandingkan dengan penambahan daun kelor sebanyak $2 \%$ dan $4 \%$.Diduga penggunaan tepung daun kelor diatas $6 \%$ dapat meningkatkan berat badan ayam yang lebih tinggi.Penelitian ini dilakukan untuk mengetahui ada tidaknya pengaruh penambahan tepung daun kelor terhadap pertumbuhan ayam joper.

Hasil akhir penelitian ini adalah sumber belajar biologi berupa poster, poster yang dibuat akan digunakan untuk peserta didik SMA. Sebelum poster digunakan untuk peserta didik, poster tersebut terlebih dulu di validasi oleh validator untuk menguji kelayakan poster.

\section{METODE}

Penelitian dilaksanakan pada tanggal 15 januari 2020 sampai 12 februari 2020. Alat yang digunakan selama penelitian yaitu timbangan anallitik untuk menimbang bahan pakan, dan berat ayam, mistar atau meteran badan, dan tempat untuk menjemur pakan. Bahan yang digunakan adalah ayam joper dari umur 25 hari sebanyak 32 ekor, tepung daun kelor, bekatul, dan air minum.

Data yang didapat dari dari 4 kali pengukuran selama penelitian akan dianalisis menggunakan uji nonparametrik yaitu uji kruskal wallis. 


\section{Pembuatan Tepung Daun Kelor}

Daun kelor (Moringa oleifera L) yang digunakan hanya bagian daunnya saja yang sudah dipisahkan dengan rantingnya. Daun kelor tersebut dicuci terlebih dulu hingga bersih, kemudian dikeringkan dengan dijemur dibawah sinar matahari langsung, setelah kering daun kelor di haluskan dengan cara diblander dan diayak agar hasil yang didapatkan benar-benar tepung yang sangat lembut.

\section{Persiapan Kandang}

Sebelum penelitian dilakukan, kandang sudah harus disiapkan terlebih dulu.Kebutuhan ayam dalam kandnag sudah harus disiapkan, seperti lampu penghangat ayam, tempat minum dan tempat makan ayam.Menyiapkan variasi campuran pakan ayam, dan menyiapkan segala sesuatu kebutuhan selama penelitian.

\section{Pelaksanaan Penelitian}

Penelitian dilakukan selama 4 minggu, dengan menggunakan ayam joper umur 25 hari.Ayam tersebut diberi air minum, dan diberi makan 2 kali sehari yaitu pada pagi dan sore hari. Pakan ayam berbeda-beda, pada kontrol diberi apkan tanpa campuran tepung daun kelor, P1 diberi tepung daun kelor sebanyak 2,5\%, P2 diberi tepung daun kelor sebanyak $5 \%$, dan P3 diberi tepung dau kelor sebanyak 7,5\%.

\section{Rancangan Penelitian}

Penelitian ini menggunakan Rancangan Acak Lengkap (RAL) dengan 4 perlakuan dengan 1 sebagai kontrol dan 4 ulangan setiap perlakuan, masingmasing ulangan terdiri dari 2 ekor ayam. Ayam yang digunakan adalah ayam joper umur 25 hari. Total ayam yang digunakan adalah 32 ekor ayam. Perlakuan dibedakan berdasarkan variasi campuran pakannya dengan pesentase daun kelor yang digunakan, yaitu:

P0 = Pakan kontrol (Tidak menggunakan tepung daun kelor atau $100 \%$ bekatul) P1 = Pakan dengan menggunakan 2,5\% tepung daun kelor dan 97,5\% bekatul. $\mathrm{P} 2=$ Pakan dengan menggunakan 5\% tepung daun kelor dan $95 \%$ bekatul. P3= Pakan dengan mengguankan 97,5\% tepung daun kelor dan 92,5\% bekatul.

\section{Variabel yang Diamati \\ Berat badan ayam joper}

Berat badan ayam joper dapat diukur dengan menggunakan timbangan analitik dengan satuan gram.Semua sampel ulangan ditimbang untuk diambil datanya.

\section{Panjang badan ayam joper}

Panjang badan ayam joper diukur menggunakan meteran badan, pengukuran panjang badan ayam diambil dari pangkal leher ayam sampai pada ekor ayam.Semua sampel ulangan diukur untuk diambil datanya.

\section{Diameter badan ayam joper}

Diameter badan ayam joper diukur menggunakan meteran badan, pengukuran diameter badan ayam dilakukan dengan cara melingkarkan meteran pada badan ayam bagian bawah dekat dengan paha. Semua sampel ulangan diukur untuk diambil datanya.

\section{HASIL \\ Berat Badan Ayam Joper}




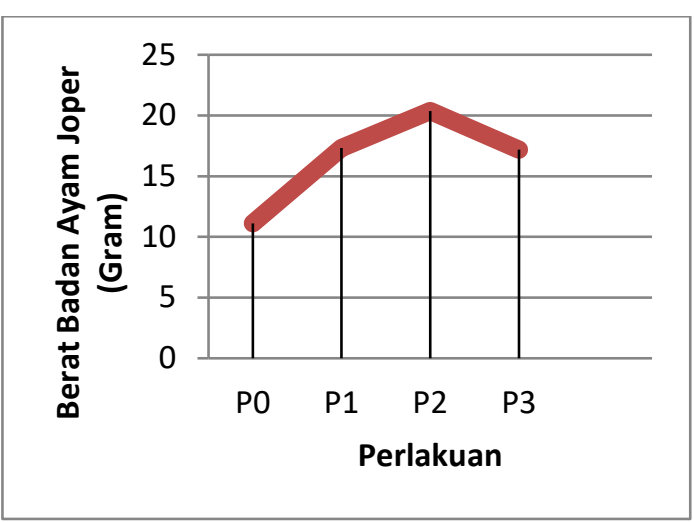

Gambar 1. Berat badan ayam joper (gram)

\section{Panjang Badan Ayam Joper}

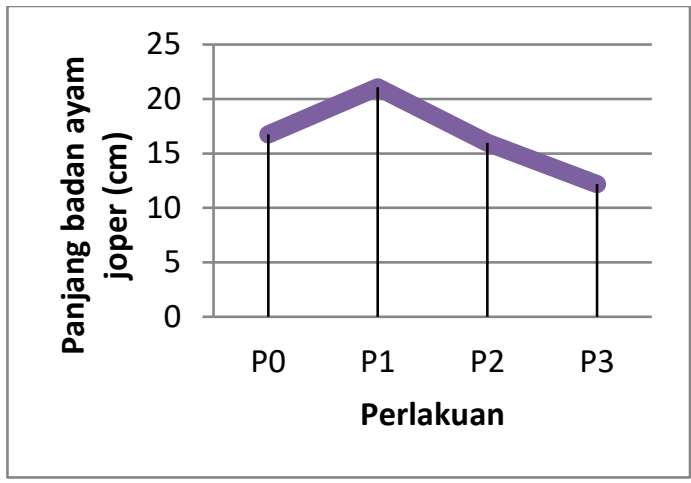

Gambar 2. Panjang badan ayam joper $(\mathrm{cm})$

\section{Diameter Badan Ayam Joper}

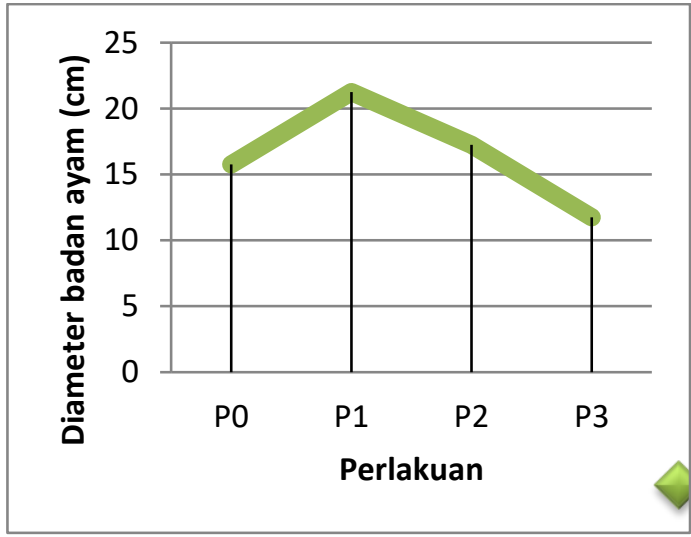

Gambar 3. Diameter badan ayam joper $(\mathrm{cm})$

\section{PEMBAHASAN}

Hasil uji statistik non-parametrik yaitu uji kruskal wallis didapatkan hasil yaitu $X^{2}$ hitung $4,09<X^{2}$ tabel 14,07 Artinya
$\mathrm{H}_{0}$ diterima. Uji kruskal wallis ini menunjukkan tidak adanya pengaruh yang nyata terhadap pertumbuhan ayam joper. Namun menunjukkan adanya ranking pertambahan berat badannya. Perengkingan dapat dilihat pada gambar 1.

Berdasarkan gambar 1 tersebut dapat terlihat bahwa pada P2 lebih tinggi dibanding perlakuan lainnya.Ini berarti pakan dengan campuran 5\% tepung daun kelor memberikan pengaruh terbaik terhadap pertambahan berat badan ayam joper meskipun pertumbuhannya masih dibawah standart.Secara statistik pakan dari campuran tepung daun kelor dan bekatul tidak memberi pengaruh yang nyata terhadap pertumuhan ayam joper namun secara biologis memberi pengaruh membuat ayam menjadi berkualiatas organik.

Hasil penelitian ini sejalan dengan penelitian Manihuruk dkk (2018) dalam penelitiannya menjelaskan bahwa penggunaan $5 \%$ tepung daun kelor membuat berat karkas ayam menjadi tinggi,dan penggunaan $10 \%$ tepung daun kelor membuat penurunan berat karkas ayam. Gakuya dkk (2014) melaporkan bahwa penambahan suplemen tepung daun kelor pada tingkat diatas 7,5\% menurunkan konsumsi ransum dan kecernaan bahan kering. Penurunan konsumsi ransum ini berdampak pada pertambahan berat badan ayam. Asrul (2016) pertambahan bobot ayam cenderung meningkat dengan ditambahkannya daun kelor sebanyak $6 \%$ jika dibandingkan dengan penambahan daun kelor sebanyak $2 \%$ dan $4 \%$.

Berdasarkan hasil penelitian yang terdahulu dapat dilihat bahwa penggunaan daun kelor sebanyak 5\% - 
$6 \%$ memberikan pengaruh terbaik untuk meningkatkan berat badan ayam joper, penggunaan daun kelor diatas 7,5\% dapat menurunkan konsumsi ransum, dan penggunaan daun kelor sebanyak $10 \%$ dapat menurunkan berat karkas. Ini berarti penggunaan daun kelor diatas $7,5 \%$ kurang efisien digunakan untuk meningkatkan berat badan ayam. Kholis dan Fariz (2010) menyatakan bahwa aroma langu yang dikeluarkan tepung daun kelor menyebabkan tingkat konsumsi tepung daun kelor rendah. Semakin banyak digunakan tepung daun kelor maka bau langu yang dikeluarkan tepung daun kelor akan semakin menyengat, namun tidak mempengaruhi produksi nya.

Perhitungan uji non parametrik untuk panjang ayam joper juga menyatakan bahwa $X^{2}$ hitung $=3,61<X_{\text {tabel }}^{2}=$ 14,07, atau hipotesis $\mathrm{H}_{0}$ diterima, artinya pakan dari campuran tepung daun kelor dan bekatul juga tidak berpengaruh nyata terhadap pertambahan panjang ayam joper. Namun memberikan perbedaan pertambahan panjang dengan menggunakan perankingan. Hasil perankingan dapat dilihat pada gambar 2 .

Berdasarkan gambar 2 tersebut dapat dilihat bahwa perlakuan P1 dengan menggunakan $2,5 \%$ tepung daun kelor terlihat lebih tinggi pertambahan panjang badannya dibandingkan pada perlakuan yang lainnya. Ini terjadi kemungkinan karena karakteristik ayam yang mudah bertambah panjang.

Perhitungan uji non parametrik untuk mengitung pertambahan diameter badan ayam joper didapatkan hasil $X_{\text {hitung }}^{2}=4,2<X_{\text {tabel }}^{2}=14,07$, atau dapat dikatakan hipotesis pada pengukuran ini menerima $\mathrm{H}_{0}$, artinya pakan dengan campuran tepung daun kelor dan bekatul tidak memberi pengaruh yang nyata terhadap pertambahan diameter badan ayam joper. Namun pertambahan diameter badannnya dapat dilihat melalui perankingan. Hasil perankingan dapat dilihat pada gambar 3 .

Berdasarkan gambar 3 tersebut dapat diketahui bahwa perlakuan P1 dengan pemberian tepung daun kelor sebanyak $2,5 \%$ merupakan pertambahan diameter tertinggi dibandingkan perlakuan yang lainnya. Hal ini terjadi kemungkinan karena memang karakteristik ayam yang pertumbuhannya membesar namun tidak menambah berat nya.

Secara statistik pakan dari campuran tepung daun kelor dan bekatul tidak memberikan pengaruh yang nyata terhadap pertumbuhan ayam joper, namun secara biologis memberikan pengaruh menjadikan ayam joper ayam yang berkualitas organik.Menurut Widodo (2010:186) ayam organik cenderung lebih rendah lemak, rendah energi, lebih kaya mineral dan protein. Disamping itu, daging ayam organik juga lebih kaya akan omega 3.

Sumber belajar poster yang dibuat telah divalidasi oleh 2 validator yakni akhli materi dan ahli desain. Skor yang didapat dari ke 2 validator akan dihitung menggunakan rumus AP $=\frac{X i}{S i t} \cdot 100 \%$, dari hasil perhitungan tersebut didapatkan hasil $91,66 \%$ atau masuk dalam kriteria sangat baik. Berdasarkan hasil perhitungan tersebut maka poster layak digunakan untuk peserta didik SMA.

\section{KESIMPULAN}

Variasi campuran tepung daun kelor dan bekatul sebanyak $(2,5 \%$ tepung daun 
kelor, 5\% tepung daun kelor dan 7,5\% tepung daun kelor) tidak memberikan pengaruh yang nyata terhadap pertumbuhan ayam joper berdasarkan perhitungan statistik.

Variasi campuran dengan 5\% tepung daun kelor dan $95 \%$ bekatul merupakan variasi terbaik dalam meningkatkan berat badan ayam joper berdasarkan perhitungan ranking uji Kruskal Wallis.

Poster yang dibuat dapat dijadikan sumber belajar untuk peserta didik, berdasarkan uji validasi oleh validator ahli materi dan ahli desain mendapatkan nilai akhir sebesar 91,66\% atau dalam kriteria sangat baik, sehingga layak digunakan sebagai sumber belajar.

\section{DAFTAR RUJUKAN}

Asrul. 2016. Pengaruh Pemberian Tepung Daun Kelor kedalam Pakan Terhadap Pertambahan Berat Badan, Konsumsi Pakan, dan Konversi Pakan Ayam Broiler. Skripsi diterbitkan. Makassar: Universitas Bosowa

Gakuya, D. W., Mbugua, P. N., Kavoi, B., and Kiama. S. G. 2014. Effect of Supplementation of Moringa oleifera Leaf Meal in Boiler Chicken Feed.International Journal of Poultry Science. 13(4):208-213.

Kholis, N., dan Hadi, F. 2010. Pengujian Bioassay Biskuit Balita yang Disuplementasi Konsentrat Protein Daun Kelor (Moringa Oleifera) pada Model Tikus Malnutrisi. Jurnal Teknologi Pertanian. 11(3):144-151.
Krisnadi, A. D. 2015. Kelor Super Nutrisi. (E-Book) Brolar: Swadaya Masyarakat. Hambatan dan Tantangan.Bogor : Institut Pertanian Bogor, Dramaga Bogor, 16680.

(https://kelorina.com/blog/ebokkelor-super-nutrisi)

Manihuruk, F. H., Ismail., Rastina., Razali., Sabri, M., Zuhrawati., dan Jalaluddin, M. 2018. Effect of Fermented Moringa Leaf (Moringa oleifera) Powder in Feed to Increase Broiler Carcass Weight. Jurnal Medika Veterinaria.12(2):103-105.

Tilong, A. D. 2012. Ternyata Kelor Penakluk Diabetes. Jogjakarta: DIVA Press.

Tuarita, M. Z., Sadek, N. F., Sukarno., Yuliana, N. D., dan Budijanto, S. 2017. Pengembangan bekatul sebagai pangan Fungsional: Peluang, Hambatan, dan Tantangan. Artikel Online. Departemen Ilmu dan Teknologi Pangan, Fakultas Teknologi Pertanian, Institut Pertanian Bogor, Dramaga Bogor,16680. (https://jurnalpangan.com/index.ph p/pangan/article/download/354/30 8)

Widodo, E. 2010. Nutrisi dan Teknik Pemeliharaan Ayam Organik. Malang: Universitas Brawijaya Press

Wulandari, M., dan Handarsari, E. 2010. Pengaruh Penambahan Bekatul Terhadap Kadar Prorein dan Sifat Organoleptik Biskuit. Jurnal Pangan dan Gizi. 02(02):55-61. 